Distribution and Abundance of Least Bell's Vireos (Vireo bellii pusillus) and Southwestern Willow Flycatchers (Empidonax traillii extimus) on the Middle San Luis Rey River, San Diego County, Southern California-2021 Data Summary

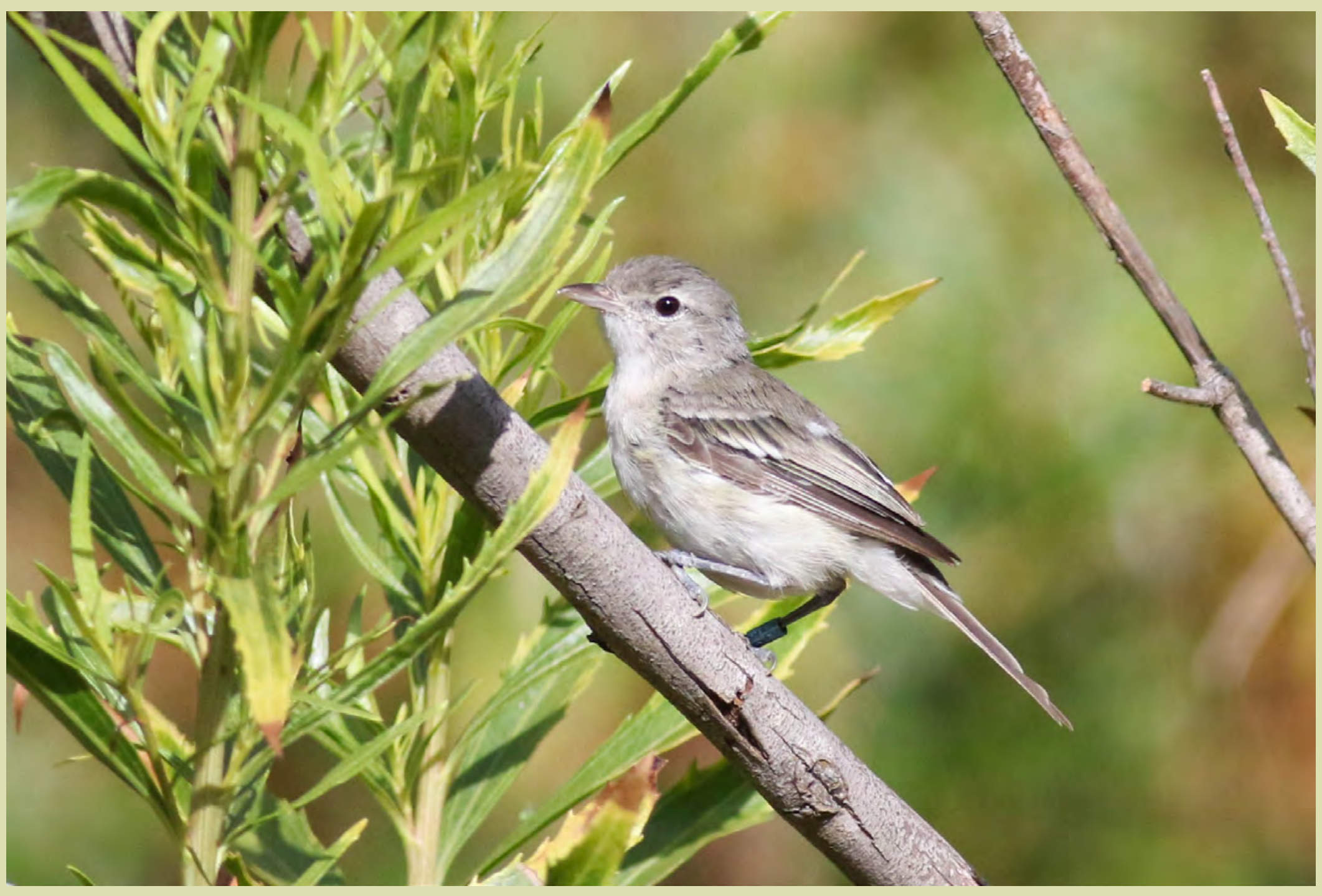

Data Report 1147 
Cover. Photograph showing Least Bell's Vireo (Vireo bellii pusillus). Photograph by Alexandra Houston, U.S. Geological Survey, July 2020. 


\section{Distribution and Abundance of Least Bell's Vireos (Vireo bellii pusillus) and Southwestern Willow Flycatchers (Empidonax traillii extimus) on the Middle San Luis Rey River, San Diego County, Southern California-2021 Data Summary}

By Lisa D. Allen and Barbara E. Kus

Data Report 1147 


\section{U.S. Geological Survey, Reston, Virginia: 2022}

For more information on the USGS - the Federal source for science about the Earth, its natural and living resources, natural hazards, and the environment—visit https://www.usgs.gov or call 1-888-ASK-USGS.

For an overview of USGS information products, including maps, imagery, and publications, visit https://store.usgs.gov/.

Any use of trade, firm, or product names is for descriptive purposes only and does not imply endorsement by the U.S. Government.

Although this information product, for the most part, is in the public domain, it also may contain copyrighted materials as noted in the text. Permission to reproduce copyrighted items must be secured from the copyright owner.

Suggested citation:

Allen, L.D., and Kus, B.E., 2022, Distribution and abundance of Least Bell's Vireos (Vireo bellii pusillus) and Southwestern Willow Flycatchers (Empidonax traillii extimus) on the Middle San Luis Rey River, San Diego County, southern California-2021 Data summary: U.S. Geological Survey Data Report 1147, 12 p., https://doi.org/10.3133/dr1147.

ISSN (online) [pending] 


\section{Contents}

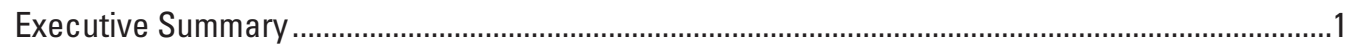

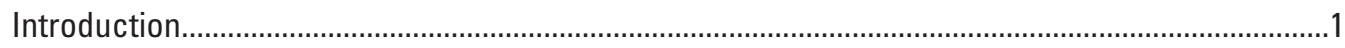

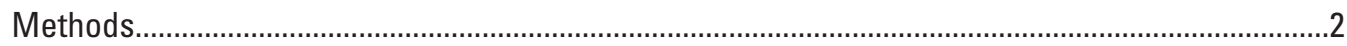

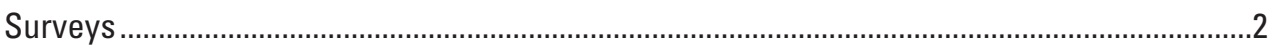

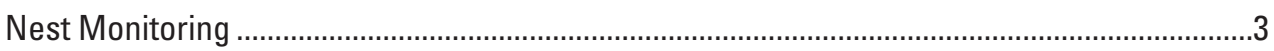

Banding

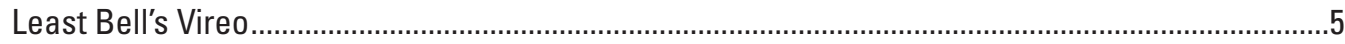

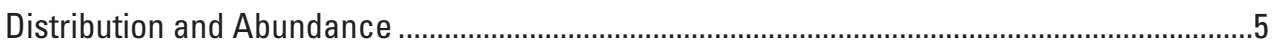

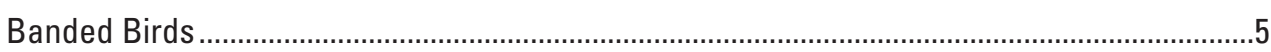

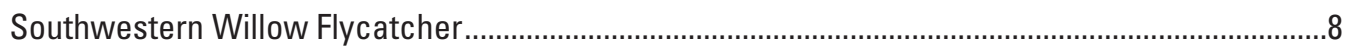

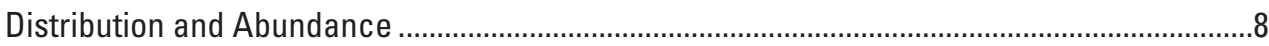

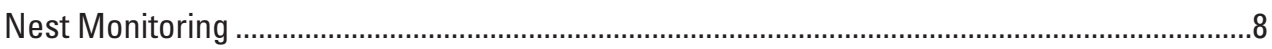

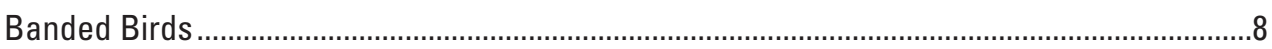

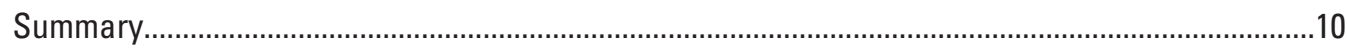

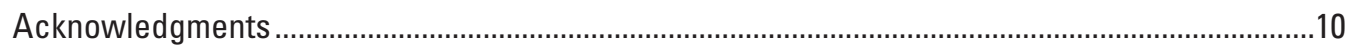

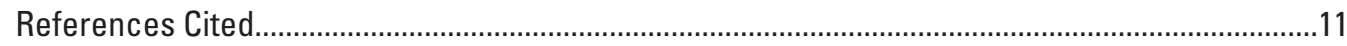

\section{Figures}

1. Map showing location of Least Bell's Vireo and Southwestern Willow Flycatcher survey area and boundaries of the Lilac Fire on the middle San Luis Rey River, San Diego County, southern California, 2021................................................

2. Map showing Least Bell's Vireo detections and breeding status on the middle San Luis Rey River, San Diego County, southern California, 2021 ....................................6

3. Map showing Southwestern Willow Flycatcher detections and breeding status on the middle San Luis Rey River, San Diego County, southern California, 2021

\section{Tables}

1. Total number and breeding status of Least Bell's Vireos detected in the study area on the middle San Luis Rey River, San Diego County, southern California, 2008-21

2. Habitat types used by Least Bell's Vireos on the middle San Luis Rey River, San Diego County, southern California, 2021

3. Band status of Least Bell's Vireos detected on the middle San Luis Rey River, San Diego County, southern California, 2021

4. Movement of banded Least Bell's Vireos and Southwestern Willow Flycatchers detected on the middle San Luis Rey River, San Diego County, southern California, 2021 


\section{Conversion Factors}

International System of Units to U.S. customary units

\begin{tabular}{lll}
\hline \multicolumn{1}{c}{ Multiply } & \multicolumn{1}{c}{ By } & \multicolumn{1}{c}{ To obtain } \\
\hline \multicolumn{3}{c}{ Length } \\
meter $(\mathrm{m})$ & 3.281 & foot $(\mathrm{ft})$ \\
kilometer $(\mathrm{km})$ & 0.6214 & mile (mi) \\
kilometer $(\mathrm{km})$ & 0.5400 & mile, nautical (nmi) \\
meter (m) & 1.094 & yard (yd) \\
\hline \multicolumn{3}{c}{ Area } \\
hectare (ha) & 2.471 & acre \\
hectare (ha) & 0.003861 & square mile $\left(\mathrm{mi}^{2}\right)$ \\
\hline
\end{tabular}

\section{Datum}

Horizontal coordinate information is referenced to the World Geodetic System of 1984 (WGS 84).

Horizontal coordinate information is referenced to the North American Datum of 1983 (NAD 83).

\section{Abbreviations}

LSLR lower San Luis Rey River

USFWS U.S. Fish and Wildlife Service 


\title{
Distribution and Abundance of Least Bell's Vireos (Vireo bellii pusillus) and Southwestern Willow Flycatchers (Empidonax traillii extimus) on the Middle San Luis Rey River, San Diego County, Southern California-2021 Data Summary
}

\author{
By Lisa D. Allen and Barbara E. Kus
}

\section{Executive Summary}

We surveyed for Least Bell's Vireos (Vireo bellii pusillus; vireo) and Southwestern Willow Flycatchers (Empidonax traillii extimus; flycatcher) along the San Luis Rey River, between College Boulevard in Oceanside and Interstate 15 in Fallbrook, California (middle San Luis Rey River), in 2021.

Surveys were conducted from April 13 to July 14 (vireo) and from May 18 to July 13 (flycatcher). We found 180 vireo territories, at least 125 of which were occupied by pairs. The vireo population size decreased by 6 percent from 2020 to 2021. In 2021, vireo territories decreased by 14 percent in the portion of the middle San Luis Rey River that burned in 2017 and decreased by 2 percent outside of the burned area.

Vireos used six different habitat types in the survey area: (1) willow-cottonwood, (2) mixed willow riparian, (3) riparian scrub, (4) upland scrub, (5) willow-sycamore, and (6) non-native. Forty percent of the vireos were detected in habitat characterized as willow-cottonwood, and 97 percent of the vireos were detected in habitat with greater than 50-percent native plant cover. Of the 14 banded vireos detected in the survey area, 3 were resighted with a full color-band combination. There were 10 other vireos with single (natal) federal bands that were recaptured, identified, and color-banded in 2021. One vireo with a single dark blue federal band, indicating that it was banded as a nestling at the lower San Luis Rey River, could not be recaptured for identification. The 10 natal vireos that were recaptured on the middle San Luis Rey River dispersed from 2.0 to 11.7 kilometers from their natal territories. Banded vireos with a known age ranged from 1 to 7 years old.

One resident flycatcher, of undetermined breeding status, was observed in the survey area in 2021. The resident flycatcher (male) was detected in a territory of mixed willow habitat with greater than 50-percent native plant cover. He was detected from May 20 to June 4, 2021, and no evidence of pairing or nesting was observed. The male flycatcher was resighted with a unique color-band combination and had occupied the same territory since 2018 .

\section{Introduction}

The Least Bell's Vireo (Vireo bellii pusillus; vireo) is a small, migratory songbird that breeds in southern California and northwestern Baja California, Mexico, from April through July. Historically abundant within lowland riparian ecosystems, vireo populations began declining in the late 1900s as a result of multiple anthropogenic factors, including habitat loss and alteration associated with urbanization and agricultural conversion of land adjacent to rivers, the expansion in range of the brood-parasitic Brown-headed Cowbird (Molothrus ater; cowbird), and the introduction of invasive exotic plant species, such as giant reed (Arundo donax), into riparian systems (U.S. Fish and Wildlife Service 1986, 1998; Franzreb, 1989; Kus, 1998, 1999; Riparian Habitat Joint Venture, 2004; Kus and others, 2020). By 1986, the vireo population in California numbered just 300 territorial males (U.S. Fish and Wildlife Service, 1986).

In response to the dramatic numeric decline of vireos in California, the California Fish and Game Commission listed the species as endangered in 1980, and the U.S. Fish and Wildlife Service (USFWS) followed suit in 1986. Since listing, the vireo population in southern California has rebounded, largely in response to cowbird control and habitat restoration and preservation (Kus and Whitfield, 2005). As of 2006, the statewide vireo population was estimated to be approximately 2,500-3,000 territories (U.S. Fish and Wildlife Service, 2006), of which approximately 10 percent occurred along the San Luis Rey River between Interstate 15 and Interstate 5 . 
Male vireos arrive on breeding grounds in southern California in mid-March. Male vireos are vocally conspicuous and frequently sing their diagnostic primary song from exposed perches throughout the breeding season. Females arrive approximately 1-2 weeks after males and are more secretive but are often seen early in the season traveling through habitat with the males. The female, with the male's help, builds an open cup nest in dense vegetation approximately 1 meter $(\mathrm{m})$ above the ground. Clutch size for Least Bell's Vireos averages three to four eggs. Typically, the female and male incubate the eggs for 14 days, and young fledge from the nest at 11-12 days of age. Nesting occurs from early April through July, but adults and juvenile birds remain on the breeding grounds into late September and early October before migrating to their wintering grounds in southern Baja California, Mexico.

The Southwestern Willow Flycatcher

(Empidonax traillii extimus; flycatcher) is one of four subspecies of Willow Flycatcher in the United States, with a breeding range including southern California, Arizona, New Mexico, extreme southern parts of Nevada and Utah, and western Texas (Hubbard, 1987; Unitt, 1987). Restricted to riparian habitat for breeding, the flycatcher has declined in recent decades in response to widespread habitat loss throughout its range and, possibly, brood-parasitism by cowbirds (Wheelock, 1912; Willett, 1912, 1933; Grinnell and Miller, 1944; Remson, 1978; Garrett and Dunn, 1981; Unitt, 1984, 1987; Gaines, 1988; Schlorff, 1990; Whitfield and Sogge, 1999). By 1993, the species was believed to number approximately 70 pairs in California (U.S. Fish and Wildlife Service, 1993) in small, disjunct populations. The flycatcher was listed as endangered by the State of California in 1992 and by the USFWS in 1995.

Flycatchers in southern California co-occur with vireos. However, unlike the vireo, which has increased tenfold since the mid-1980s in response to management practices alleviating threats (U.S. Fish and Wildlife Service, 2006), the number of flycatchers has remained low. Currently, most flycatchers in California are concentrated at one site, the upper San Luis Rey River near Lake Henshaw in San Diego County (Howell and Kus, 2021). Outside of this site, flycatchers occur as small, isolated populations of one to six pairs. Data on the distribution and demography of the flycatcher, as well as identification of factors limiting the species, are critical information needs during the current stage of recovery planning (Kus and others, 2003; Kus and Whitfield, 2005).

Male flycatchers begin arriving in southern California at the end of April and females arrive approximately 1 week later. While on the breeding grounds, males sing repeatedly from exposed perches. Once the pair bond is established, the female builds an open cup nest that is usually placed in a branch fork of a willow (Salix spp.) or plant with a similar branching structure approximately $1-3 \mathrm{~m}$ above the ground. The typical clutch of three to four eggs is laid in May-June. Females incubate for approximately 12 days and nestlings fledge within 12-15 days, in early July. Adults usually depart from their breeding territory in mid-August and early September to their wintering grounds in central Mexico and northern South America.

The purpose of this study was to document the status of vireos and flycatchers along an 18-kilometer $(\mathrm{km})$ stretch of the San Luis Rey River from College Boulevard in Oceanside, California, east to Interstate 15 (middle San Luis Rey River; fig. 1).

Our goals for vireos were to (1) determine abundance and distribution of vireos on the middle San Luis Rey River to facilitate population trend analyses and (2) collect information on dispersal and site fidelity of banded vireos. Our goals for flycatchers were to (1) determine the size and composition of the flycatcher population on the middle San Luis Rey River, (2) document and monitor the nesting activities of resident flycatchers, and (3) band and resight all flycatchers to facilitate the estimation of flycatcher survivorship and movement.

These data, when compared with data from other sites, will inform natural resource managers about the status of these endangered species on the San Luis Rey River and guide modification of land use and management practices as appropriate to ensure the species' continued existence.

\section{Methods}

\section{Surveys}

U.S. Geological Survey biologists conducted vireo and flycatcher surveys on the middle San Luis Rey River by following standard survey techniques for vireos (U.S. Fish and Wildlife Service, 2001) and flycatchers (Sogge and others, 2010). Vireo and flycatcher surveys were conducted under USFWS permit ESPER0004080_0. Four surveys for vireos were conducted throughout the study area between April 14 and July 13, 2021, and three surveys for flycatchers were conducted between May 18 and July 13, 2021. Observers walked slowly through or adjacent to suitable riparian habitat, listening and searching for vireos and flycatchers, occasionally playing a recording of a vireo or flycatcher song to elicit a territorial response. Surveys typically began at sunrise and were completed by early afternoon, avoiding conditions of high winds and extreme heat, which can reduce bird activity and detectability.

For each vireo or flycatcher encountered, observers recorded age (adult or juvenile), sex, breeding status (paired, single, undetermined, or transient), and whether the bird was banded. A vireo or flycatcher was considered transient if detected only once or, if more than once, detections were less than 2 weeks apart. Transient status was assigned only in years with more than three surveys. To determine geographic coordinates, the vireo and flycatcher locations were mapped using ESRI Collector (Environmental Systems Research Institute, 2020) on an Android phone, with 1- to 15-meter (m) accuracy (World Geodetic System of 1984, WGS 84). 
Dominant native and exotic plants were recorded at each territory location, and percent cover of native vegetation was estimated using cover categories of less than 5 percent, 5-50 percent, 51-95 percent, and greater than 95 percent. Overall habitat type was specified according to the following categories:

Mixed willow riparian: Habitat dominated by one or more willow species, including Goodding's black willow (Salix gooddingii), arroyo willow (Salix lasiolepis), and red willow (Salix laevigata), with mule fat (Baccharis salicifolia) as a frequent co-dominant.

Willow-cottonwood: Willow riparian habitat in which Fremont cottonwood (Populus fremontii) is a co-dominant.

Willow-sycamore: Willow riparian habitat in which California sycamore (Platanus racemosa) is a co-dominant.

Sycamore-oak: Woodlands in which California sycamore and coast live oak (Quercus agrifolia) occur as co-dominants.

Riparian scrub: Dry or sandy habitat dominated by sandbar willow (Salix exigua) or mule fat, with few other woody species.

Upland scrub: Coastal sage scrub adjacent to riparian habitat.

Non-native: Areas vegetated primarily with non-native species, such as giant reed and tamarisk (Tamarix ramosissima).

A large wildfire (Lilac Fire) occurred at the San Luis Rey River in December 2017, during the time of year when vireos and flycatchers were not present. The wildfire burned approximately 1,651 hectares (ha), including 300 ha of riparian habitat within the middle San Luis Rey River study area (fig. 1).

\section{Nest Monitoring}

The flycatchers observed during surveys that were suspected to be resident birds (for example, observed in more than one survey period, pair vocalizations heard, or evidence of nesting observed) were revisited within 3 days of the detection date. When present, resident birds were observed for evidence of nesting, and nests were located and monitored by following standard protocol (Rourke and others, 1999). To minimize the chances of leading predators or cowbirds to nest sites, nests were visited only as frequently as needed to collect sufficient data. Typically, there were three to four visits per nest, spaced approximately 5-10 days apart, depending on the stage of the nest when initially detected. The first visit was timed to determine the number of eggs laid, the next to confirm hatching and age of young, and the last to band the nestlings. After a nest became inactive, six possible nest fates were assigned based on the following parameters:

1. Nests that fledged at least one flycatcher young were considered successful. Fledging was confirmed by detection of young outside the nest.

2. Nests found empty or destroyed before the estimated fledge date and where the adult flycatchers were not found tending fledgling(s) were considered depredated.

3. Previously active nests that were subsequently abandoned by adult flycatchers after one or more cowbird eggs were laid in the nest were considered to have failed because of nest parasitism. Any nests that fledged cowbird young without fledging flycatcher young also were considered to have failed because of nest parasitism.

4. Nests that were seen under construction but were never completed were classified as incomplete.

5. Nests failing for reasons such as poor nest construction, the collapse of a host plant that caused a nest's contents to be dumped onto the ground, or the presence of a clutch of infertile eggs, were classified as failing because of other causes that were known.

6. Nests that appeared intact and undisturbed but were abandoned with flycatcher eggs or nestlings were classified as having failed because of unknown causes.

\section{Banding}

Mist nets were used to recapture adult vireos and flycatchers that were previously banded as nestlings with a single metal band (natal) to determine their original banding location. When captured, birds were fitted with colored leg bands in a unique color-band combination so that individuals could be identified in the future without recapture. Additionally, attempts were made to capture and color-band unbanded adult flycatchers. Flycatcher nestlings, when present, were banded at 7-10 days of age. Each flycatcher nestling received a silver aluminum federal numbered band on the right leg.

All summary data are presented as mean \pm standard deviation. Data from 2008 to 2020 used in comparison with current (2021) data are available in Allen and others (2017, 2018), and Allen and Kus (2019, 2020, 2021). 


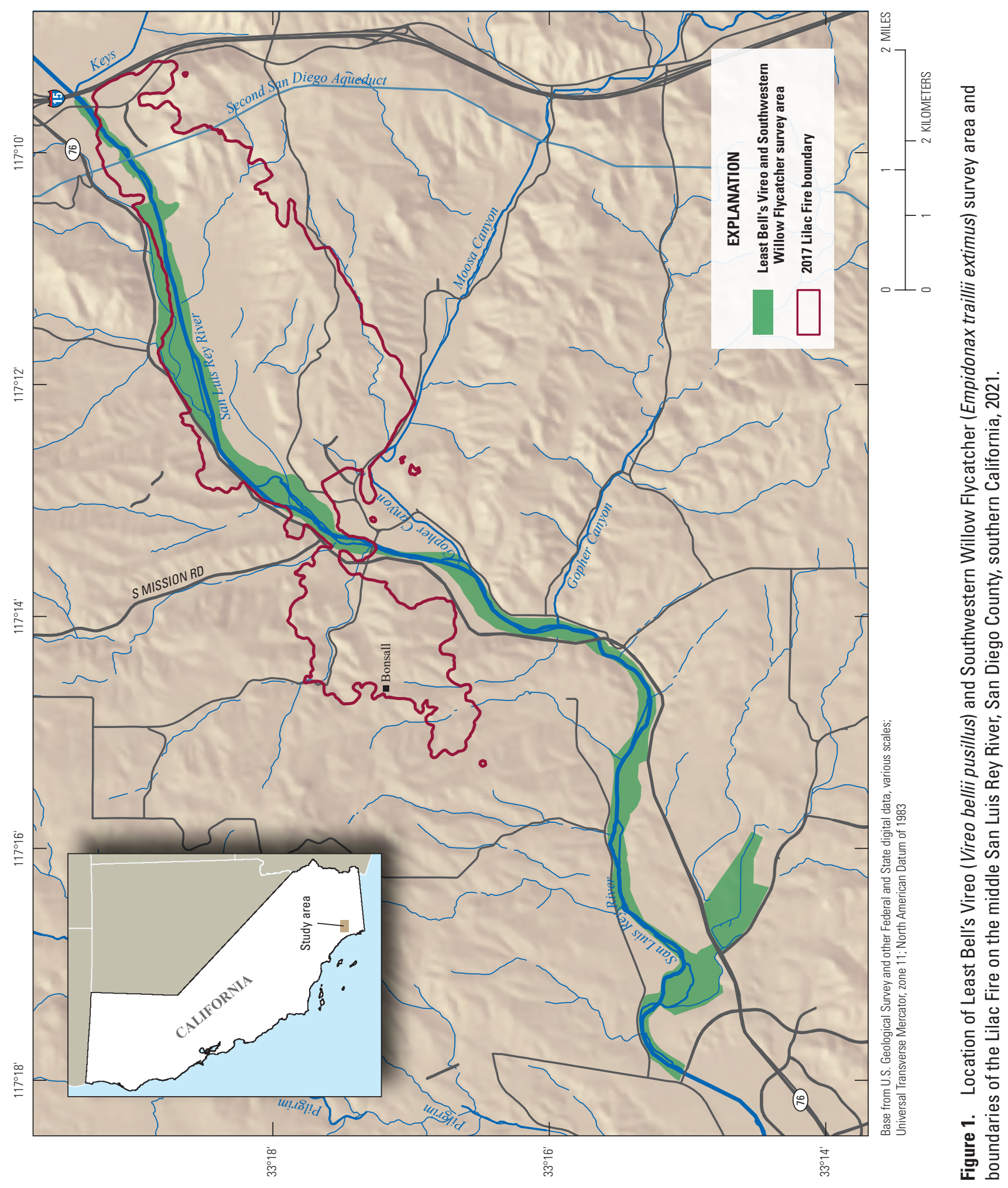




\section{Least Bell's Vireo}

\section{Distribution and Abundance}

A total of 180 vireo territories (125 paired, 55 of undetermined status) and 3 transients were detected on the middle San Luis Rey River in 2021 (table 1 and fig. 2). The vireo population size decreased by 6 percent relative to 2020 but was well above the 13-year average (2008-20) of $140 \pm 25$ territories. Most of the decline was within the burned area, where the number of vireo territories dropped by 14 percent (from 70 to 60 territories), compared to 2 percent (from 122 to 120 territories) outside of the burned area.

Table 1. Total number and breeding status of Least Bell's Vireos (Vireo bellii pusillus) detected in the study area on the middle San Luis Rey River, San Diego County, southern California, 2008-21.

[Number of single males: Least Bell's Vireo nest monitoring did not occur in 2008, 2011, and 2015-21; therefore, the number of times a territory was visited was not sufficient to determine whether the territory contained a single male. Transients: Transients not included in the total number of territorial males. Transient status not assigned in years when fewer than four surveys were conducted (2008-14, 2019). Abbreviation: NA, not applicable]

\begin{tabular}{llrccc}
\hline Year & $\begin{array}{c}\text { Total number } \\
\text { of territorial } \\
\text { males }\end{array}$ & $\begin{array}{c}\text { Number } \\
\text { of pairs }\end{array}$ & $\begin{array}{c}\text { Number of } \\
\text { birds with } \\
\text { undetermined } \\
\text { status }\end{array}$ & $\begin{array}{c}\text { Number } \\
\text { of single } \\
\text { males }\end{array}$ & Transient \\
\hline 2008 & 100 & 47 & 53 & NA & NA \\
2009 & 115 & 67 & 48 & NA & NA \\
2010 & 146 & 115 & 30 & 1 & NA \\
2011 & 126 & 69 & 57 & NA & NA \\
2012 & 101 & 66 & 29 & 6 & NA \\
2013 & 110 & 69 & 39 & 2 & NA \\
2014 & 168 & 134 & 33 & 1 & NA \\
2015 & 141 & 92 & 49 & NA & 2 \\
2016 & 142 & 106 & 36 & NA & 6 \\
2017 & 146 & 107 & 39 & NA & 5 \\
2018 & 148 & 90 & 58 & NA & 6 \\
2019 & 179 & 124 & 55 & NA & NA \\
2020 & 192 & 150 & 42 & NA & 4 \\
2021 & 180 & 125 & 55 & NA & 3 \\
\hline
\end{tabular}

Least Bell's Vireos used six different habitat types in the survey area. Forty percent of the vireos were detected in habitat characterized as willow-cottonwood, 39 percent were detected in mixed willow riparian, 17 percent were detected in riparian scrub, 2 percent were detected in upland scrub, 1 percent were detected in willow-sycamore, and 1 percent were detected in non-native habitat. Ninety-seven percent (175/180) of vireo territories were detected in habitat with greater than 50-percent native plant cover (table 2).

The most commonly recorded dominant species at vireo territories included red or arroyo willow, Fremont cottonwood, and mule fat. The most prevalent exotic species were poison hemlock (Conium maculatum) and black mustard (Brassica nigra).

\section{Banded Birds}

In 2021, 14 banded vireos were detected on the middle San Luis Rey River (tables 3 and 4). Three banded vireos (one male and two females) that were banded prior to 2021 were resighted with a unique color-band combination and were previously detected on the middle San Luis Rey River. One color-banded female vireo was last detected in 2018, and the other two banded vireos (one male and one female) were last detected in 2020. All three of the color-banded vireos that were detected on the middle San Luis Rey River moved 100 m or less from their previous territories (table 4).

There were 11 natal vireos ( 8 males and 3 females) detected on the middle San Luis Rey River in 2021. These vireos had only a single (natal) dark blue federal band, indicating that they were originally banded as nestlings on the lower San Luis Rey River (LSLR). There were 10 natal vireos that were recaptured, identified, and given a unique color-band combination; 1 vireo (male) was not recaptured (table 3). The 10 natal vireos that were recaptured on the middle San Luis Rey River dispersed from 2.0 to $11.7 \mathrm{~km}$ from their natal territories (table 4).

Banded vireos of known age ranged from 1 to 7 years old. The oldest identified vireo was a 7-year-old female that was banded in 2015 as an adult on the LSLR. This female was not detected in 2019 or 2020 but has occupied a territory on the middle San Luis Rey River for multiple years (table 4). 


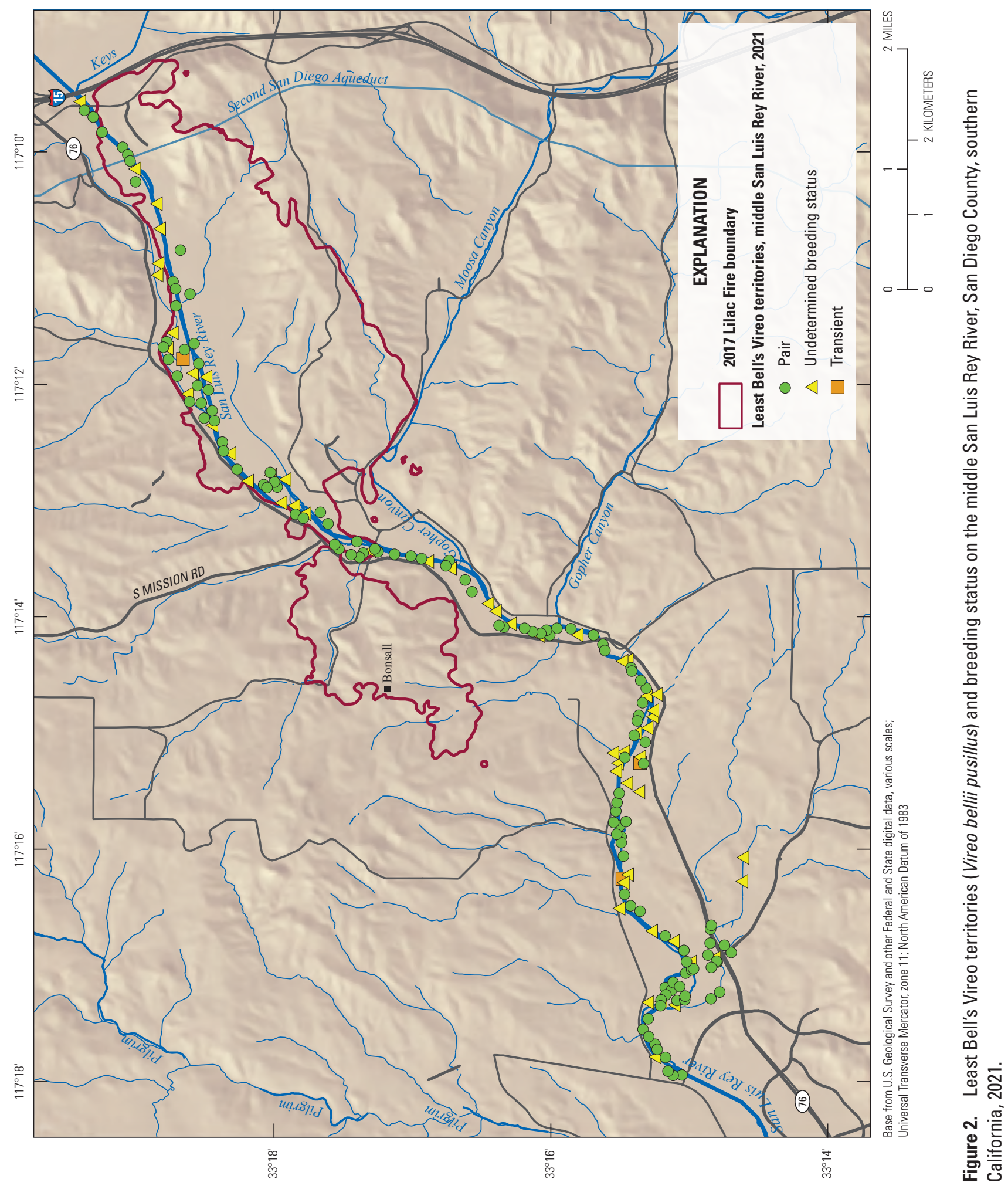


Table 2. Habitat types used by Least Bell's Vireos (Vireo bellii pusillus) on the middle San Luis Rey River, San Diego County, southern California, 2021.

[Mixed willow riparian: Habitat dominated by one or more willow species, including Goodding's black willow, arroyo willow, and red willow, with mule fat as frequent co-dominant. Willow-cottonwood: Willow riparian habitat in which Fremont cottonwood is a co-dominant. Riparian scrub: Dry and sandy habitat dominated by sandbar willow or mule fat, with few other woody species. Upland Scrub: Coastal sage scrub adjacent to riparian habitat. Willow-sycamore: Willow riparian habitat in which California sycamore is a co-dominant. Non-native: Areas vegetated exclusively with non-native species, such as giant reed and tamarisk. Abbreviations: >, greater than; $<$, less than]

\begin{tabular}{|c|c|c|c|c|c|c|}
\hline \multirow[b]{2}{*}{ Habitat type } & \multicolumn{6}{|c|}{ Number of Least Bell's Vireo territories } \\
\hline & $\begin{array}{c}>95 \text { percent } \\
\text { native plant cover }\end{array}$ & $\begin{array}{c}50-95 \text { percent } \\
\text { native plant cover }\end{array}$ & $\begin{array}{c}5-50 \text { percent } \\
\text { native plant cover }\end{array}$ & $\begin{array}{c}<5 \text { percent } \\
\text { native }\end{array}$ & Total & $\begin{array}{c}\text { Percentage } \\
\text { of total }\end{array}$ \\
\hline Willow-cottonwood & 48 & 24 & 0 & 0 & 72 & 40 \\
\hline Mixed willow riparian & 34 & 36 & 0 & 0 & 70 & 39 \\
\hline Riparian scrub & 13 & 17 & 1 & 0 & 31 & 17 \\
\hline Upland scrub & 2 & 0 & 2 & 0 & 4 & 2 \\
\hline Willow-sycamore & 1 & 0 & 0 & 0 & 1 & 1 \\
\hline Non-native & 0 & 0 & 1 & 1 & 2 & 1 \\
\hline Total & 98 & 77 & 4 & 1 & 180 & 100 \\
\hline
\end{tabular}

Table 3. Band status of Least Bell's Vireos (Vireo bellii pusillus) detected on the middle San Luis Rey River, San Diego County, southern California, 2021.

[Previously identified on the middle San Luis Rey River: All birds were originally banded as nestlings or adults outside of the study area but have had established territories in the study area for multiple years.]

\begin{tabular}{lccccc}
\hline \multirow{2}{*}{ Band status } & \multicolumn{2}{c}{$\begin{array}{c}\text { Previously identified on the } \\
\text { middle San Luis Rey River }\end{array}$} & \multicolumn{2}{c}{ Immigrants } & \multirow{2}{*}{ Total } \\
\cline { 2 - 5 } & Male & Female & Male & Female & \\
\hline Uniquely banded prior to 2021 & 1 & 2 & 0 & 0 & 3 \\
Natal recaptured in 2021 & 0 & 0 & 7 & 3 & 10 \\
Natal not recaptured & 0 & 0 & 1 & 0 & 1 \\
Total & 1 & 2 & 8 & 3 & 14 \\
\hline
\end{tabular}


Table 4. Movement of banded Least Bell's Vireos (Vireo bellii pusillus) and Southwestern Willow Flycatchers (Empidonax traillii extimus) detected on the middle San Luis Rey River, San Diego County, southern California, 2021.

[2020 and 2021 territory: LSLR, lower San Luis Rey River (Interstate 5 to College Boulevard); Natal, natal vireos were originally banded as nestlings with a single numbered federal band. Color-band combination: Left Leg: Right Leg (colors read top to bottom). Metal band acronyms: Mdb, numbered dark blue band; Msi, numbered silver band; pupu, purple. Plastic Band acronyms: BPST, black-pink striped; BYST, black-yellow striped; DBWH, dark blue-white split; DPDB, dark pink-dark blue split; DPDP, dark pink; DPWH, dark pink-white split; PUWH, purple-white split; PUYE, purple-yellow split; WHDB, white-dark blue split; WHPU, white-purple split; YEBK, yellow-black split; YEYE, yellow. Pin-striped metal band acronyms: rprp, royal purple. Sex: F, female; M, male. Abbreviations: km, kilometer; -, no band]

\begin{tabular}{|c|c|c|c|c|c|c|}
\hline $\begin{array}{c}\text { Year } \\
\text { originally } \\
\text { banded }\end{array}$ & 2020 territory & $\begin{array}{c}2021 \\
\text { territory }\end{array}$ & $\begin{array}{c}\text { Distance } \\
\text { moved (km) }\end{array}$ & $\begin{array}{l}\text { Color-band } \\
\text { combination }\end{array}$ & Sex & $\begin{array}{l}\text { Minimum } \\
\text { age in } 2021 \\
\text { (years) }\end{array}$ \\
\hline \multicolumn{7}{|c|}{ Least Bell's Vireos } \\
\hline 2015 & MSL112 (2018 territory) & MSL137 & 0.3 & WHDB Mdb : DPDP & $\mathrm{F}$ & 7 \\
\hline 2017 & MSL03 & MSL105 & 0.9 & BPST pupu : Mdb & M & 4 \\
\hline 2019 & MSL113 & MSL106 & 0.7 & DBWH : BPST Mdb & $\mathrm{F}$ & 2 \\
\hline 2019 & WCAR (LSLR Natal) & MSL132 & 2.0 & PUWH : BPST Mdb & $\mathrm{F}$ & 2 \\
\hline 2019 & DGAR (LSLR Natal) & MSL142 & 2.2 & DPDB : Mdb & M & 2 \\
\hline 2019 & CACE (LSLR Natal) & MSL110 & 5.2 & YEBK pupu : Mdb & M & 2 \\
\hline 2019 & CLAD (LSLR Natal) & MSL230 & 6.7 & WHPU : WHDB Mdb & M & 2 \\
\hline 2019 & CSTR (LSLR Natal) & MSL109 & 7.3 & PUYE : WHPU Mdb & $\mathrm{F}$ & 2 \\
\hline 2019 & CSNE(LSLR Natal) & MSL118 & 11.7 & PUYE : BYST Mdb & $\mathrm{F}$ & 2 \\
\hline 2020 & CNED (LSLR Natal) & MSL147 & 1.5 & Mdb : DPWH pupu & M & 1 \\
\hline 2020 & CCOT (LSLR Natal) & MSL155 & 1.8 & DPWH Mdb : PUWH & M & 1 \\
\hline 2020 & DMAD (LSLR Natal) & MSL227 & 7.8 & DPDP Mdb : pupu & M & 1 \\
\hline 2020 & CKES (LSLR Natal) & BO15 & 11.2 & YEYE Mdb : DPWH & M & 1 \\
\hline Unknown & LSLR & MSL114 & Unknown & $-: \mathrm{Mdb}$ & M & 1 \\
\hline \multicolumn{7}{|c|}{ Southwestern Willow Flycatchers } \\
\hline 2016 & $\mathrm{BO} 01 \mathrm{~F}$ & $\mathrm{BO} 01 \mathrm{~F}$ & 0.0 & Msi : rprp & M & 5 \\
\hline
\end{tabular}

\section{Southwestern Willow Flycatcher}

\section{Distribution and Abundance}

One resident male flycatcher of undetermined breeding status and one transient flycatcher were detected on the middle San Luis Rey River in 2021 (fig. 3). The resident flycatcher was detected on May 20, 2021, and established a territory between May 20 and June 4, 2021; no female was ever detected in the territory. This was consistent with the flycatcher population in 2020, when one resident male flycatcher was observed. One transient flycatcher that could not be identified to subspecies was detected on May 27, 2021, but was not detected on subsequent surveys. Both flycatchers used habitat characterized as mixed willow with greater than 50 -percent native plant cover.

\section{Nest Monitoring}

No flycatcher nesting activities were observed on the middle San Luis Rey River in 2021.

\section{Banded Birds}

One resident flycatcher (male) with a unique color-band combination was detected on the middle San Luis Rey River in 2021. The male flycatcher has occupied the same territory (BO01F) from 2018 to 2021. The flycatcher was originally banded as a nestling on the middle San Luis Rey River in 2016, at BO02F territory, and given a unique color combination in 2018 (table 4). 


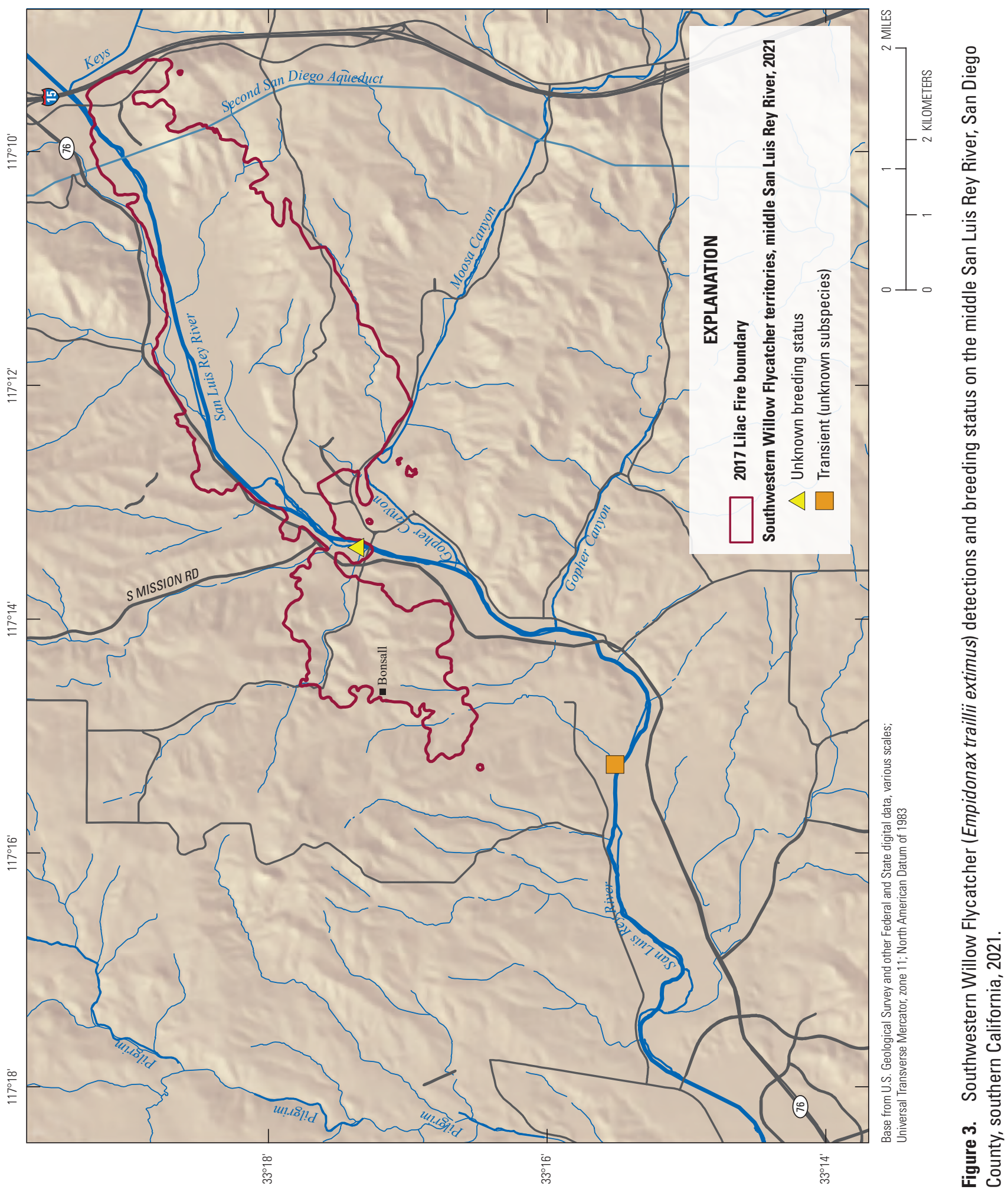




\section{Summary}

The number of Least Bell's Vireo territories on the middle San Luis Rey River decreased by 6 percent from 2020 (192) to 2021 (180). The number of vireo territories on the middle San Luis Rey River has fluctuated between 100 and 192 since 2008. In 2021, the number of vireo territories decreased within the burned and unburned parts of the middle San Luis Rey River, although the population in the burned area (60 territories) was higher than that before the 2017 fire (56 territories). This decrease was likely driven by a decrease in the range-wide vireo population. Similarly, vireos decreased by 24 percent downstream on the lower San Luis Rey River and decreased by 14 percent on Marine Corps Base Camp Pendleton in 2021 (B. Kus, U.S. Geological Survey, unpub. data, 2021)
In 2021, we documented vireos immigrating to the survey area from the lower San Luis Rey River. Eleven natal vireos that were originally banded as nestlings on the lower San Luis Rey River immigrated to the middle San Luis Rey River in 2021.

Southwestern Willow Flycatcher territories were consistent with 2020; only one resident male was detected, with no successful breeding documented in 2021.

\section{Acknowledgments}

The authors would like to thank the U.S. Geological Survey biologists who assisted in the data collection for this project: Armand Amico, Annabelle Bernabe, Alexandra Houston, Scarlett Howell, Rachelle McLaughlin, Jessica Medina, Ben Stubbs, Michelle Treadwell, and Stéphane Vernhet. 


\section{References Cited}

Allen, L.D., Howell, S.L., and Kus, B.E., 2017, Distribution and abundance of Least Bell's Vireos (Vireo bellii pusillus) and Southwestern Willow Flycatchers (Empidonax traillii extimus) on the Middle San Luis Rey River, San Diego, southern California - 2016 data summary: U.S. Geological Survey Data Series 1065, 11 p., accessed October 12, 2021, at https://doi.org/10.3133/ds1065.

Allen, L.D., Howell, S.L., and Kus, B.E., 2018, Distribution and abundance of Least Bell's Vireos (Vireo bellii pusillus) and Southwestern Willow Flycatchers (Empidonax traillii extimus) on the Middle San Luis Rey River, San Diego County, southern California—2017 data summary: U.S. Geological Survey Data Series 1082, 12 p., accessed October 12, 2021, at https://doi.org/10.3133/ds1082.

Allen, L.D., and Kus, B.E., 2019, Distribution and abundance of Least Bell's Vireos (Vireo bellii pusillus) and Southwestern Willow Flycatchers (Empidonax traillii extimus) on the middle San Luis Rey River, San Diego County, southern California-2018 data summary: U.S. Geological Survey Data Series 1109, 12 p., accessed October 12, 2021, at https://doi.org/10.3133/ds1109.

Allen, L.D., and Kus, B.E., 2020, Distribution and abundance of Least Bell's Vireos (Vireo bellii pusillus) and Southwestern Willow Flycatchers (Empidonax traillii extimus) on the Middle San Luis Rey River, San Diego County, southern California-2019 data summary: U.S. Geological Survey Data Series 1122, 11 p., accessed October 12, 2021, at https://doi.org/10.3133/ds1122.

Allen, L.D., and Kus, B.E., 2021, Distribution and abundance of Least Bell's Vireos (Vireo bellii pusillus) and Southwestern Willow Flycatchers (Empidonax traillii extimus) on the middle San Luis Rey River, San Diego County, southern California-2020 data summary: U.S. Geological Survey Data Series 1134, 11 p., accessed October 12, 2021, at https://doi.org/10.3133/ds1134.

Environmental Systems Research Institute (ESRI), 2020, Collector Release 20.2.2: Redlands, Calif., Environmental Systems Research Institute.

Franzreb, K.E., 1989, Ecology and conservation of the endangered Least Bell's Vireo: U.S. Fish and Wildlife Service, Biological Report, v. 89, no. 1, 17 p., accessed October 20, 2021, at https://apps.dtic.mil/dtic/tr/fulltext/u2/a322886.pdf.

Gaines, D., 1988, Birds of Yosemite and the east slope: Lee Vining, Calif., Artemesia Press, 123 p.
Garrett, K., and Dunn, J., 1981, Birds of southern CaliforniaStatus and distribution: Los Angeles, Calif., Los Angeles Audubon Society, 408 p.

Grinnell, J., and Miller, A.H., 1944, The distribution of the birds of California: Berkeley, Calif., Pacific Coast Avifauna, no. $27,608 \mathrm{p}$.

Howell, S.L., and Kus, B.E., 2021, Distribution and abundance of Southwestern Willow Flycatchers (Empidonax traillii extimus) on the upper San Luis Rey River, San Diego County, California-2020 data summary: U.S. Geological Survey Data Series 1140, 11 p., accessed October 20, 2021, at https://doi.org/10.3133/ds1140.

Hubbard, J.P., 1987, The status of the Willow Flycatcher in New Mexico: Santa Fe, N. Mex., New Mexico Department of Game and Fish, Endangered Species Program, 29 p.

Kus, B.E., 1998, Use of restored riparian habitat by the endangered Least Bell's Vireo (Vireo bellii pusillus): Restoration Ecology, v. 6, no. 1, p. 75-82, accessed October 20, 2021, at https://doi.org/10.1046/j.1526-100x.1998.06110.x.

Kus, B.E., 1999, Impacts of Brown-Headed Cowbird parasitism on the productivity of the endangered Least Bell's Vireo: Studies in Avian Biology, v. 18, p. 160-166.

Kus, B.E., Beck, P.P., and Wells, J.M., 2003, Southwestern Willow Flycatcher populations in California-Distribution, abundance, and potential for conservation: Studies in Avian Biology, v. 26, p. 12-21.

Kus, B., Hopp, S.L., Johnson, R.R., and Brown, B.T., 2020, Bell's Vireo (Vireo bellii), version 1.0, in Poole, A.F., ed., Birds of the world: Ithaca, NY, Cornell Lab of Ornithology, accessed October 25, 2021, at https://doi.org/10.2173/bow.belvir.01.

Kus, B.E., and Whitfield, M.J., 2005, Parasitism, productivity, and population growth-Response of Least Bell's Vireos (Vireo bellii pusillus) and Southwestern Willow Flycatchers (Empidonax traillii extimus) to cowbird (Molothrus spp.) control: Ornithological Monographs, v. 57 , no. 57, p. 16-27, accessed October 25, 2021, at https://doi.org/10.2307/40166811.

Remson, J.V., Jr., 1978, Bird species of special concern in California: California Department of Fish and Game, Wildlife Management Division, Administrative Report 78-1, 67 p.

Riparian Habitat Joint Venture, 2004, The riparian bird conservation plan-A strategy for reversing the decline of riparian associated birds in California (ver. 2): California Partners in Flight, 156 p., accessed October 25, 2021, at http://www.prbo.org/calpif/pdfs/riparian_v-2.pdf. 
Rourke, J.W., McCarthey, T.D., Davidson, R.F., and Santaniello, A.M., 1999, Southwestern Willow Flycatcher nest monitoring protocol: Phoenix, Arizona Game and Fish Department, Nongame and Endangered Wildlife Program, Technical Report 144, 34 p.

Schlorff, R.W., 1990, Report to the Fish and Game Commission-Status review of the Willow Flycatcher (Empidonax traillii) in California: State of California, Resources Agency, Department of Fish and Game, Wildlife Management Division, Department Candidate Species Status Report 90-04, 23 p., accessed October 25, 2021, at https://nrm.dfg.ca.gov/documents/Default.aspx.

Sogge, M.K., Ahlers, D., and Sferra, S.J., 2010, A natural history summary and survey protocol for the Southwestern Willow Flycatcher, U.S. Geological Survey Techniques and Methods, book 2, chap. A10, 38 p., accessed October 25, 2021, at https://doi.org/10.3133/tm2A10.

Unitt, P., 1984, The birds of San Diego County: San Diego Society of Natural History, Memoir 13, 276 p.

Unitt, P., 1987, Empidonax traillii extimus-An endangered subspecies: Western Birds, v. 18, p. 137-162.

U.S. Fish and Wildlife Service, 1986, Endangered and threatened wildlife and plants; Determination of endangered status for the Least Bell's Vireo, Final rule: Federal Register, v. 51, p. 85, p. 16474-16482.
U.S. Fish and Wildlife Service, 1993, Proposal to list the Southwestern Willow Flycatcher as an endangered species and to designate critical habitat: Federal Register, v. 58, p. 39495-39522.

U.S. Fish and Wildlife Service, 1998, Draft recovery plan for the Least Bell's Vireo (Vireo bellii pusillus): Portland, Oreg., U.S. Fish and Wildlife Service, 139 p.

U.S. Fish and Wildlife Service, 2001, Least Bell's Vireo survey guidelines: U.S. Fish and Wildlife Service, Internal Memo, accessed March 29, 2021, at https://www.fws.gov/ pacific/ecoservices/endangered/recovery/documents/LBVir eo.2001.protocol.pdf.

U.S. Fish and Wildlife Service, 2006, Least Bell's Vireo (Vireo bellii pusillus) 5-year review summary and evaluation: Carlsbad, Calif., U.S. Fish and Wildlife Service, Carlsbad Fish and Wildlife Office, $24 \mathrm{p}$.

Wheelock, I.G., 1912, Birds of California-An introduction to more than three hundred common birds of the state and adjacent islands: Chicago, Ill., A.C. McClurg and Company.

Whitfield, M.J., and Sogge, M.K., 1999, Range-wide impact of Brown-headed Cowbird parasitism on the Southwestern Willow Flycatcher (Empidonax traillii extimus): Studies in Avian Biology, v. 18, p. 182-190.

Willett, G., 1912, Birds of the Pacific slope of southern California: Pacific Coast Avifauna, v. 7.

Willett, G., 1933, A revised list of the birds of southwestern California: Pacific Coast Avifauna, v. 21. 
For more information concerning the research in this report, contact the

Director, Western Ecological Research Center

U.S. Geological Survey

3020 State University Drive East

Sacramento, California 95819

https://www.usgs.gov/centers/werc

Publishing support provided by the U.S. Geological Survey

Science Publishing Network, Sacramento Publishing Service Center 


\section{$\frac{\mathbb{2}}{\mathrm{C}}$}

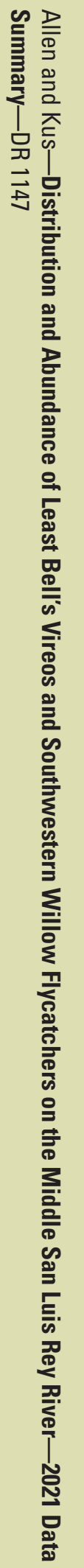

ISSN (online) [pending] https://doi.org/10.3133/dr1147 